\title{
The Digital Divide in the United States and Worldwide
}

\author{
Janice C. Sipior, Burke T. Ward, and Joanna Z. Marzec \\ Villanova University, USA
}

\author{
|anice.sipior@vilanova.edu, burke.ward@vilanova.edu, marzec@netreach.net
}

\begin{abstract}
The Digital Divide has been defined as a gap between those with access to new information technologies and those without. The term is also used to characterize the disparity between those who can effectively use information technology and those who cannot. This paper explores the digital divide within the United States (U.S.) and worldwide. Factors contributing to the widening of the gap are identified, including differences in income, age, education, race, household type, and geographic location. In an effort to reduce the Digital Divide, initiatives have been undertaken, such as promoting increased competition to reduce equipment and internet connection costs and U.S. government legislation to provide incentives such as tax relief to Internet providers serving specific geographic areas, and the global initiative by the G-8 Heads of State to help coordinate worldwide government efforts in closing the Digital Divide.
\end{abstract}

Keywords: Digital Divide, Internet access, Social impact, Socioeconomic factors

\section{Introduction}

The Digital Divide has been defined as a divide between those with access to new information technologies and those without, or in other words, it is the gap between the 'technology haves' and 'have-nots' (Novak et al., 2000 and Wilhelm, 2000). The term Digital Divide is also used to characterize the disparity between those who can effectively use new information and communication tools, such as the Internet, and those who cannot. No matter how we define the term, there is consensus that some sort of divide exists that excludes many from benefiting from information technology and the telecommunications infrastructure, increasingly crucial to economic success and personal advancement. The Digital Divide is viewed as an important domestic and global issue. "The Digital Divide is arguably the single, largest, segregating force in today's world. If it is not made a national priority, a generation of children and families will mature without these tools that are proving to be the key to the future" (PR Newswire, 2000b).

This paper explores the digital divide within the United States (U.S.) and worldwide. Factors contributing to the widening of the digital divide are identified to provide in-

Material published as part of this proceedings, either on-line or in print, is copyrighted by the author with permission granted to the publisher of Informing Science for this printing. Permission to make digital or paper copy of part or all of these works for personal or classroom use is granted without fee provided that the copies are not made or distributed for profit or commercial advantage AND that copies 1) bear this notice in full and 2) give the full citation on the first page. It is permissible to abstract these works so long as credit is given. To copy in all other cases or to republish or to post on a server or to redistribute to lists requires specific permission from the author. sight into how the gap might be reduced. Initiatives addressing the critical challenges presented by the divide are presented. Finally, a global perspective on the problem is discussed to understand the far-reaching problems, implications, and potential for solutions.

\section{Factors Widening the Digital Divide}

Internet access continues to expand worldwide. While the exact number is difficult to determine, current estimates range from 130 million (Nielsen, 2000) to 322 million internet users worldwide (ecommerce.gov, 2000). There are an estimated 46.5 million users in the U.S. alone, expected to reach 90 million in the next four years (Strategis Group, 2000). Increasing numbers of users are able to access information, transfer files, send email, work with people from remote sites, bank, shop and perform countless other functions.

Although Internet use has been growing exponentially, the gap between high income technology 'haves' and low income 'have-nots' is getting wider. According to a study by Jupiter Communications, at least one-half of all U.S. households earning less than $\$ 15,000$ will remain unconnected through 2005 (Wilhelm, 2000). The gap between well-educated segments of the U.S. and the not-so-welleducated, wealthy and poor, white and non-white, and rural dwellers and urban residents have widened significantly in the last five years (www.ntia.doc.gov, 1999). The most important factors separating 'haves' and 'have-nots' in the U.S. were identified as income, age, education, race, 


\section{The Digital Divide}

household type, and geographic location. Each of these is discussed in the following sections.

\section{Income}

Usage of the Internet is directly related to income level (www.ntia.doc.gov, 1999). Although a combination of factors determines if an individual is online, income is the strongest predictor. Across all groups, online penetration rises as income rises. Those with lower income have the lowest access to the Internet. In households with income between $\$ 5,000$ and $\$ 9,999,12.1$ percent use the Internet, contrasted with 58.9 percent in the highest income bracket of $\$ 75,000$ and higher. Households with incomes of $\$ 75,000$ or higher are more than twenty times more likely to have access to the Internet than those at the lowest income level and are more than nine times as likely to have a computer at home (cyberatlas.internet.com, 1999a). Lowincome white families are three times more likely to own a computer than Hispanic families and two times more likely to have a computer at home than a comparable Black household. According to the Kaiser Family Foundation report, only 23 percent of low-income children have access to the Internet at home compare to 58 percent of children in high-income families (Wilhelm, 2000).

Between 1997 and 1998, the divide between the highest and lowest income levels is reported to have grown 29 percent (cyberatlas.internet.com, 1999b). Dividing the population into quintiles reveals that the bottom 20 percent earned about 3.6 percent of total income in 1998 compared with 4.2 percent in 1973 , whereas the top 20 percent earned more than 49 percent versus 44 percent in 1973 (Murphy, 2000). The Center on Budget and Policy Priorities estimates that from 1977 the cash earnings of the poorest fifth of the U.S. population fell about nine percent, middle class earnings rose eight percent, and upper-income earnings increased by 43 percent (Murphy, 2000).

According to Fortune magazine, earnings in the U.S. are more unequal today than at any time in the past 60 years (Murphy, 2000). Income inequality is increasing due to the rising inequality in wages, among other factors. Today, society is rewarding highly educated people even more than in the past, a trend that sociologists refer to as "skillbased technological change" (Murphy, 2000). It is no surprise that college graduates can expect to earn more than those who earn only a high school diploma. In the current information age, demand for labor has shifted toward the skilled and away from the unskilled.

\section{Age}

Age is an important determinant of Internet usage. Among those $35-44$ years of age 39.8 percent use the Internet, the largest percentage among age groups. In general however, Internet usage is high among all age groups, with the exclusion of seniors. Seniors, aged 55 years and older, rank lowest in usage among all age groups, with 11 percent. Children aged two to twelve and seniors over 65 lag behind the national average in online penetration (Schreiber, 2000). However, this gap is expected to compress in the next five years. Internet usage among children is projected to increase to 62 percent by 2005 from 32 percent in 2000 . Senior penetration is projected to rise to 48 percent, up from 16 percent currently (Schreiber, 2000).

\section{Education}

Education is a critical factor in understanding what facilitates or limits Internet access, according to a Stanford University study (digitaldividenetwork.org, 2000). Level of education and Internet usage are highly correlated (www.ntia.doc.gov, 1999). Those who have earned a college degree are more than nine times as likely to use the Internet than those with an elementary school education. The dramatic difference in use may be attributable to literacy. "Computers [can be placed] in community centers, but only the literate people are likely to go use them" (Symonds, 2000a). Despite efforts to make the Internet a true multimedia experience, the vast majority of online content is text-based. Such content is useless to individuals if they cannot read. As many as 44 million American adults, or almost one in four, are functionally illiterate and another 50 million have limited literacy skills according to the Department of Education's National Literacy Survey (digitaldividenetwork.org, 2000). The disturbing fact is that between 1997 and 1998 the disparity between the highest and the lowest level of education increased 25 percent (cyberatlas.internet.com, 1999b). Across minority groups, the differences are even more visible. Only 56 percent of Latino students graduate from high school and only 19 percent complete courses required to get into college (Anonymous, 1999). The differences in level of education go hand-in-hand with income disparities because most people who are poor are uneducated.

Another educational factor influencing Internet use is Internet access within schools. In high-poverty neighborhood schools, students are less likely to have instructional rooms connected to the Internet than are students in more affluent communities. Almost 70 percent of schools in the 
U.S. have at least one computer, but less than 15 percent of classrooms have Internet access (Hoffman, 2000).

At the college level, students exhibit the highest use of the Web because they most likely have access at school, even if they do not have Internet access at home or at work (Hoffman, 2000). However, a closer look at Internet use among college freshman reveals that even among students, there are disparities in access. A significant gap exists between private college freshmen use of the Internet for research, 90.2 percent, and those in public black colleges, 77.6 percent (Hoffman, 2000).

\section{Race}

Internet use varies by race (www.ntia.doc.gov, 1999).

White individuals use the Internet more than either Blacks or Hispanics, at 37.7 percent, 19 percent and 16.6 percent respectively. Blacks and Hispanics are less connected at home and in other places such as school, work, libraries, and community centers. The gap in Internet access between White and Hispanic households and White and Black households is now five percent wider than in 1997 (www.ntia.doc.gov, 1999). Between 1994 and 1998 computer ownership among Latinos in the U.S. grew from 13 percent to 30 percent. Nevertheless, the gap between nonHispanic Whites and Hispanics has actually increased by 42 percent and the gap in Internet access has widened by 56 percent in the last year (Beneton Foundation, 1999).

However, regardless of race, higher income levels correspond to an increased likelihood of owning a computer at home (Novak, 1998). The same is true for education with higher educational levels coinciding with a higher possibility of owning a computer at home.

\section{Household Type}

Family structure impacts household access to the Internet. Married couples with children less than eighteen years of age have the highest Internet penetration of 37.6 percent, while female-headed households with children have the lowest at 22.3 percent. In recent years, the number of single-parent families has grown, particularly those headed by never-married mothers. Single-parent families earn about half as much as two-parent households. At the same time, there has been a significant increase in families in which both parents work, contributing to higher income levels. The likelihood of owning a computer and having Internet access increases for families with higher incomes. There are almost 212 times more individuals working in the rich- est quintile than in the poorest one. Further, less than a third of those in the poorest fifth live in households headed by a married couple, whereas in the wealthiest fifth of our population about 90 percent live in married-couple families (Murphy, 2000).

\section{Geographic Location}

In general, the western states have the highest Internet usage with 35.5 percent, and the southern states the lowest with 29.8 percent. Two-thirds of small communities across the U.S. are expected to have high-speed Internet access. The last mile - connecting the remaining third - is a challenge. Providing high-speed access through traditional means - through copper wires and fiber optics - to areas with a small population base is too expensive. Wireless access might be a cheaper alternative. However, extending Internet services to some states will be difficult. In North Carolina for example, eight to ten percent of the population still do not have telephone service (Barton, 2000).

Another issue contributing to the digital gap in remote areas is cost. The advanced telecommunications services used by business for high-speed Internet access cost $\$ 21,000$ per year in Columbus County, NC compare with $\$ 3,000$ per year in urban areas like Raleigh, NC (FDCH Federal Dept., 2000b). Residents of twelve states - called the "Disconnected Dozen" (Alabama, Arkansas, Idaho, Iowa, Maine, Montana, New Hampshire, North Dakota, Oklahoma, South Dakota, West Virginia, and Wyoming) are more likely to be left behind as the rest of the country moves into the digital future.

A recent report issued by the Department of Agriculture and Commerce pointed out that less than five percent of towns with a population of 100,000 or less and one percent of towns with a population of 250,000 or less have broadband DSL or cable modem services (PR Newswire, 2000a). The report highlighted concerns of the American Corn Growers Association, "This is a startlingly low percentage given the fact that, according to the 1990 census, 22.3 million households - or 25 percent of the U.S. population - lived in towns of less than 2,500 or in areas outside of towns altogether. This is the nuts and bolts reality that is locking rural Americans out of the Internet economy." In Virginia, for example, 46.6 percent of households have a computer. However, this number is misleading because northern counties account for 39 percent of the Internet users, but the region represents less than 30 percent of the state's population. In Virginia, the rural areas are on the unfortunate side of the Digital Di- 


\section{The Digital Divide}

vide, lagging behind urban and suburban areas, just as poor families lag behind rich ones in Internet access (Barakat, 2000).

One of the most startling contrasts between the technology 'haves' and 'have-nots' is between Silicon Valley's Palo Alto and East Palo Alto. Median family income in Silicon Valley was $\$ 87,000$ in 1999 and the median price of a house was $\$ 410,000$. On the other end, East Palo Alto, a low-income community measuring approximately 2.5 square miles with a population of about 25,000 , has a relatively high poverty level, the largest high school dropout rate in the Bay Area, and the lowest property value in San Mateo County. Although, the city makes up just 3.5 percent of San Mateo County's population, 25 percent of East Palo Alto residents receive welfare. Unemployment within East Palo Alto is about three times the level for the county and the median family income in 1990 was less than 50 percent of the county-wide median. The 1990 Census indicates that 21 percent of residents had income below the federally designated poverty level. There is only one computer for every 28 students, as compared to the one-to-nine ration for the entire state (FDCH Federal Dept., 2000a).

\section{Impact of the Digital Divide}

A nation's future technological capabilities depend on the skills and technologies it develops today. New information and communication technologies, like the Internet, are transforming the way we live, learn, and work. Nations that can master the potential of these technologies can look forward to greatly expanded economic growth and significantly improved human welfare. In today's information age, the computer skills are becoming essential for future competitiveness. Lack of Internet access diminishes economic opportunities for many Americans, especially in small towns and rural areas, in low-income, low-educated families. Access to information is being transformed from an advantage to a necessity.

Poorly educated people will not be able to take advantage of digital technology. Those who lack basic computer skills will be unable to apply for one of the many unfilled position in the high-tech industry. For example, Latinos make up 23 percent of Silicon Valley population but in 33 high-tech firms, only about seven percent of the workforce are Latinos (Anonymous, 1999). Low-skilled well-paid jobs are disappearing. High-tech companies such as Hewlett-Packard contracts its manufacturing to specialists, many of them abroad (Anonymous, 1999). Although owning a computer or being connected to the Web is not essential, in the digital economy it is necessary for success. According to a recent report from the Information Technology Association of America there will be an estimated 850,000 unfilled position in high-tech industries in 2000 and people who do not possess the right skills will not be able to take advantage of such opportunities. Communities will suffer from an inability to fill positions due to an underskilled pool of potential employees. Already, workers over 40 are finding that youth is preferred over experience and stored knowledge is devalued.

Another consequence of the Digital Divide is the inability of people who do not have Internet access to benefit from the wide range of services offered through the Web. In 1996, the national conventions of both the Republican and Democratic parties were carried over the Internet, giving opportunities for feedback and interaction. While the Internet has the potential to create well-informed and empowered consumers, it will also help to change the rather passive relationship most people have with the government and politics (Symonds, 2000a). However, people who did not own a computer or did not have Internet access could not participate in the "point-and-click" debate. In March 2000, Arizona registered voters who had Internet access were given an opportunity to vote online in the Democratic Party primary during the 96-hour period leading up to the opening of the polls (Wilhelm, 2000). Those without Internet access were able to exercise their voting rights for just one day at the polling place. Some argue that as long as Internet access is heavily weighted toward the rich, online voting will weaken the voice of minorities and the poor. If the Digital Divide is not bridged, the very powerful communication tools meant to enrich lives will only serve as a social divider.

\section{The Importance of Bridging the Digital Divide}

The growth of information technology (IT) and the increasing expansion of electronic commerce are changing the way individuals work, communicate, vote, purchase goods, and obtain information. More and more today's jobs require technical skills and familiarity with new technologies. Many jobs and many universities expect students to have Internet access.

The U.S. has played a leading role in the information revolution. However, the advantages that the U.S. was able to secure by its lead in telecommunications and computing technologies are not insurmountable. Governments of 
other countries, private sector and various foundations are eager to win the race to the next generation of technology.

Access to technology is important to American social and economic well being and will be essential for children growing up in the new century. The Internet is a very powerful tool and can improve the education and future prospects of young people. The U.S. Department of Commerce estimates that by the end of 2000,60 percent of jobs will require skills with technology. If the Digital Divide is left untouched the gap between the technology 'haves' and 'have-nots' will create a barrier which would prevent people on the unfortunate side of the Digital Divide from obtaining a quality job and from benefiting from life-long educational opportunities.

There is also an international aspect in bringing the Internet technology to everyone in U.S. If the U.S. does not tackle the issue aggressively; it may be left behind by the competition. Japan, for example, is committed to universal deployment of the Internet technology and projects to complete deployment by 2001. Other countries such as Singapore, Sweden, and Canada have similar plans (Broadband Internet Access Act of 2000).

\section{What is Being Done to Bridge the Digital Divide?}

There is no single solution to reduce the Digital Divide. Business and government leaders recognize the importance of bringing everyone onto the information grid. One way to help close the gap is through promotion of competition. In recent years, we have seen competition among personal computer $(\mathrm{PC})$ providers has resulted in a reduction in the selling price to below US $\$ 1,000$. The competition among PC producers and Internet providers will increase the use of other Internet-accessing devices, such as television, palm computers, and Internet phones. Lower costs for PCs and free Internet access are helping to narrow the digital divide in terms of income levels. A survey by the Yankee Group revealed that 47 percent of new Internet users had free Internet accounts. For many U.S. households, the Internet has become as much a part of daily life as television. Nevertheless, the high cost of Internet access was still cited as a reason for not having Internet access (www.ntia.doc.gov, 1999). If we consider the cost of the computer and the monthly bills followed by toll calling for ISP service, the Internet is still beyond many low-income households' budget. Although, many companies are getting involved in bridging the Digital Divide, much more has to be done to close the technology gap and create digital opportunities for all.

The U.S. government is seeking to close the Digital Divide through legislation that provides incentives to Internet providers. In September, the U.S. Congress signed the Broadband Internet Access Act of 2000. The bill provides tax relief for the deployment of high speed Internet. A ten percent tax relief is allocated for deployment of the current generation 1.5-megabit service and 20 percent for the deployment of the next 22-megabit service to rural, lowincome areas, and other residential areas. Any Internet provider deploying broadband access to targeted areas through standard telephone wire, coxial cable, fiber optics, terrestrial wireless, satellite, or any other medium would be eligible for the tax credit. This legislation limits the credit to years $2001-2005$ to ensure the progress and promote vigorous competition. Any service provider deploying the bandwidth connection to the targeted area will qualify for the tax credit. However, the provider must achieve ten percent market penetration in order to receive the credit.

Since the cost is still one of the most significant factors why many do not own a computer and do not have Internet access, there are an increasing number of projects to bring Internet technologies to low-income communities. The Commerce Department has funded 332 such projects in all 50 states (Shepard, 1998). One of the first and most successful programs is "Plugged In" a program in East Palo Alto that operates a community center with computers and Internet access. The Plugged In program was established in 1992 to ensure that everyone in East Palo Alto California has the opportunity to fully benefit from all that information technology has to offer. Plugged In operates three programs: Plugged In Enterprises, a program for teenagers, Plugged In Greenhouse, a creative arts and technology studio for children, and the Technology Access Center, community copy, cyber-library, and telecom center. In 1992, the nonprofit Boys Harbor agency that teaches underprivileged children in New York's Harlem and the Bronx introduced computers to the curriculum to make the kids comfortable with the technology that is essential in the future (Shepard, 1998). Another objective of the U.S. government is to get more computers in schools. Since 1996, Congress has spent $\$ 5$ billion on wiring schools and public libraries. In Virginia, for example, all 350 of the state's libraries have some type of public Internet access (Barakat, 2000). 


\section{The Digital Divide}

The issue of language barriers as a factor in the Digital Divide has also been addressed. For example, in September 2000, BlueLight.com, Kmart Corporation, Yahoo! Inc. and Spinway, Inc. announced the launch of a customized Spanish-language version of a free Internet service (Business Wire, 2000b). BlueLight.com is distributing millions of free Spanish-language CD-ROMs through 1,600 Kmart stores nationwide. By installing the free software onto their computers, consumers will have Internet access with the Yahoo start page, which includes personalized information in Spanish, including relevant news, sports, weather and travel information. The consumers can also sign up for the Yahoo!Mail account and install an instant messaging service (Business Wire, 2000b). To further promote the Spanish-language free Internet service more than 50,000 CD-ROMs will be distributed at selected Major League Soccer games across the country this season. In November 2000, BlueLight.com will be hosting classes at ten Kmart stores in America, called 'Get to Know the Internet' and will be promoting its free Internet service and low-cost computer (\$499) (Business Wire, 2000b).

There are also programs to provide the Internet technology to Native Americans. StarBand Communications, the Southwest Navajo Nation Virtual Alliance (SNNVA) and Northern Arizona University (NAU) want to provide a high-speed Internet connection to some of the most isolated groups in the nation. The Internet connectivity will be delivered to 120 locations within Navajo, Hopi, and Havasupai reservations, some of the most remote areas of Arizona, Utah, and New Mexico (Business Wire, 2000a). Through this initiative, Native Americans will be able to access NAU's distance education programs. StarBand will provide equipment, installation services, and Internet subscriptions for the program at a reduced cost. To fund this program SNNVA received a grant from the Technologies Opportunities Program (TOP) of the U.S. Commerce Department's National Telecommunications and Information Administration (NTIA).

To assist senior citizens in accessing the Internet, "Generations Online," customized software was introduced in September 2000. Senior citizens are among the least connected to the Internet. The "Generations Online" is written in plain English and provides step-by-step instructions for going on line. It was design for use in libraries, retirement centers, elder housing sites, and senior centers, where seniors can work individually or be a part of computer classes. The Philadelphia Senior Learning Center has a computer lab with a 12-station state-of-the-art computer lab, one of the first in the nation to introduce "Generations Online."
Today, the Learning Center offers 27 computer classes in two labs (Digital Divide Newsletter, No 3).

\section{Digital Divide as a Global Issue}

The Digital Divide is worldwide issue. It has been estimated that of 322 million people online as of March 2000, less than one percent or 2.77 million live in Africa (ecommerce.gov, 2000). Internet penetration is uneven, not only around the world, but also throughout Europe. There are about 108 million Internet users in Europe, which account, on average, for a penetration rate of about 34 percent.

However, the rate varies among European countries from 65.2 percent in Sweden to 45.6 percent in U.K., 31.6 percent in France and 11.4 in Portugal (Rohde, 2000).

Worldwide, there is even more disparity. For example, in Mozambique, only one in 3,000 people have Internet access. Joaquim Alberto Chissano, the president of Mozambique, said, "New York City has more Internet hosts than the entire African continent" (Hoffman, 2000).

According to the Computer Industry Almanac report from November 1999, there were only 57.5 Internet users per 1,000 people around the world (Rohde, 2000). That ranged from 492 Internet users in North America, to 7.88 users per 1,000 people in Middle East and Africa. By some estimates, the U.S dominance in Internet users will be overshadow by other countries. In three years, 50 percent of Internet users will come from other parts of the world. Within six years, Chinese will likely be the most widely used language on the Internet (Rohde, 2000).

Before the information infrastructure can be deployed in the developing parts of the world, reliable sources of energy (solar, wind, tidal, or conventional means) have to be provided. The Global Information Infrastructure Commission's guide for developing countries notes that 33 percent of the world's population has no electricity at all and about 33 percent has only intermittent electricity. Another key factor for development is a telecom infrastructure. While the world has 6 billion people, there are only 0.8 billion telephone lines. Over 80 percent of the world has yet to make a phone call. Both governments and the private sector must be involved in helping the poor and disadvantaged find jobs and benefit from the new technologies. Some governments must first deal with the gender discrimination issue and other equality problems in their countries.

The G-8 Heads of State have committed themselves to establish the Digital Opportunity Taskforce to help coordinate government efforts in closing the Digital Di- 
vide. There have also been a number of smaller but equally important initiatives to bridge the Global Digital Divide. American Assistance for Cambodia, a nonprofit group based in Tokyo, is trying to deliver a permanent Internet connection to a primary school in the village of Robib, Cambodia. Former Asian correspondent for Newsweek Bernard Krisher, who runs the nonprofit group, is hoping to assist in economic transformation of a Cambodian region, where the average per capita income is about \$37 a year (Markoff, 2000). The program will provide education and Internet access to 400 school students.

\section{Conclusion}

Although some progress has been made in closing the Digital Divide, more can be done. The challenge is to further knock down the barriers that keep some out of the new economy. Although developing an information infrastructure is the basic building block, other initiatives should be undertaken to connect those in poor and rural areas. The key is education. Providing schools with the Internet access is a necessary first step. Providing training to those on the unfortunate side of the Digital Divide is essential.

\section{References}

Anonymous. (1999). United States: The Digital Divide. The Economist. Apr 17.

Barakat, M. (2000). Task Force to Expand Internet Access. The Associated Press State \& Local Wire. Jul 18.

Barton, P. (2000). Officials Try Bridging Digital Divide with HighSpeed Connections Equipment. Gannett News Service. May 5.

Broadband Internet Access Act of 2000. http://www.americanforthe digitalbridge.com

(2000a). StarBand Communications and Northern Arizona University Provide High-Speed Internet to Remote Indian Nations. Business Wire. Sep 12.

(2000b). BlueLight.com Teams with Kmart, Yahoo! And Spinway to Unveil Totally Free Internet Service en Espanol; Free ISP Service is Launched with Spanish-English CD-ROM Designed for Bilingual Hispanic Community Available in Kmart Stores. Business Wire. Sep 18.

(2000). Clinton/Gore Administration: From Global Digital Divide to Digital Opportunity. President Clinton and Other G-8 Leaders to Create Digital Opportunity Taskforce. Jul 22.

\section{HItp./WWw.ecommetce.govt}

Beneton Foundation. (1999). The Digital Divide and the US Hispanic Population. Digital Best. (1999a) Digital Divide More Economic than Ethnic. Jul 8. http://cyberatlas.internet.com/big_picture/demographics/article/0, 523,5901_395581,00.htm1

(1999b). Digital Divide Persists in US.

http://cyberatlas.internet.com/big_picture/demographics/article/0, 523,5901_158701,00.htm!

(2000a). Background on the Digital Divide and East Palo Alto, California. FDCH Federal Department and Agency Documents. Apr 17.

(2000b). The President's New Markets Trip: From Digital Divide to Digital Opportunity Expanding High-Speed Internet Access in Rural America. FDCH Federal Department and Agency Documents. Apr 26. http://ww.pub.whitehous.gov/urires/I2R?urn:pdi://oma.eop.gov.us/2000/4/19/15.text.1

Hoffman, D.L., Novak, T.P. and Schlosser, A.E. (2000). The Evolution of the Digital Divide: How Gaps in Internet Access May Impact Electronic Commerce. Journal of Computer-Mediated Communication. 5(3). March. http://www.ascusc.org//]cmc/vols/issues/hollman.htm/

Hoffman, T. (2000). Leaders: Education key to bridging digital divide. Computerworld. Sep 11.

Markoff, J. (2000). It Takes a World Wide Web to Raise a Village. The New York Times. Aug 7.

Murphy, C. (2000). Are the Rich Cleaning Up? Fortune. Sep 4.

Nielsen NetRatings (2000). http:// 209.249.142.29/nnpm/owa/Nrpublicreports.usagemonthly

Novak, T.P. and Hoffman, D.L. (2000). Bridging the Digital Divide: The Internet of Race on Computer Access and Internet Use. http://www2000.ogsm.vanderbilt.edu/digital.divide.htmI

(1999). Falling Through the Net: Defining the Digital Divide. WWw.nuta.doc.gov/ntiahometdigitaldivide

(2000a). Rural America Needs More Than Virtual Solutions to the Digital Divide: Leading Agricultural Organizations Call on Presidential Candidates for Answers. PR Newswire. Jun 19.

(2000b). Congress Seeks to Bride Gap between Tech Haves and Have Nots; Legislation Aimed at Inner Cities, Rural America, 13 New Co-Sponsors Join Bills Bridging Digital Divide Possible. PR Newswire. Sep 12.

Rohde, G.L. (2000). How do we know where we are going if we do not know where we are? Aug 3. nttp://www.ecommerce.gov/

Schreiber, D. and Husak, M. (2000). Income and Age, Not Ethnicity, to Remain Largest Gap for US Digital Divide. Jun 15. http://www.jup.com/company/pressrelease.jsp?doc=pr000615\&que Fy=digital\% $/$ divide

Shepard, S. (1998). Tech Gap Divides the Races. Cox News Services. Nov 11. 


\section{The Digital Divide}

Strategis Group (2000).

nttp://www.strategisgroup.com/press/pubs/intdbl.htm

Symonds, M. (2000a). Government and the Internet: Digital Democracy. The Economist. Jun 24.

Symonds, M. (2000b). Government and the Internet: Haves and Havenots. The Economist. Jun 24.

What Do We Mean When We Say 'Digital Divide?' http://Www.digitaldividenetwork.org/tdd.adp Retrieved November 15,2000 .

Wilhelm, A.G. and Thierer, A.D. (2000). Should Americans Be Concerned about the Digital Divide? Insight on the News. 16 (33). Sep 4.

(2000). The Yankee Group Reports Significant Shift in Online Consumer Population. Oct 16.

http://www.yankeegroup.com/webfolder/yg21a.nsf/press/D3582D3 G9EFDE9F98525697AO044E0TE?OpenDocument

Backhouse, J., Liebenau, J., \& Land, F. (1991). On the discipline of information systems. Journal of Information Systems, 1, 19-27. Notice that this is of style "References".

Biggs, J. B., \& Collis, K. F. (1982). Evaluating the quality of learning: The SOLO taxonomy. New York: Academic Press.
Katz, I. M. (2000), Cats and Their Servants. Warsaw: Informing Science Press. Accessed April 1, 2000 at http://newmillenium.org/fools.htm

\section{Biographies}

Janice C. Sipior is an Associate Professor of Management Information Systems at Villanova University. Her current research interests include ethical and legal aspects of information technology, system development strategies, and knowledge management.

Burke T. Ward is an Associate Professor in the Department of Accountancy and a faculty member of The Graduate Tax Program at Villanova University. Dr. Ward has published numerous articles in the areas of taxation, information systems, and employment law. His current research interests include the legal aspects of information technology, estate planning, and business succession planning.

Joanna Z. Marzec is currently an MBA student at Villanova University. She expects to complete her degree in May 2001. 